\title{
Team Games Tournament dan Numbered Head Together dalam Pembelajaran Bangun Datar
}

\author{
Dwi Rejeki ${ }^{1}$, Esti Harini ${ }^{2}$, Istiqomah Istiqomah ${ }^{3}$, Fitria Sulistyowati ${ }^{*}$ \\ 1,23,4Pendidikan Matematika, Universitas Sarjanawiyata Tamansiswa, Yogyakarta, Indonesia; \\ dwire16@gmail.com ${ }^{1}$ \\ esti@ustjogja.ac.id $^{2}$ \\ istiqomah@ustjogja.ac.id ${ }^{3}$ \\ *fitria.sulistyowati@ustjogja.ac.id ${ }^{4}$
}

\begin{abstract}
Abstrak. Tujuan dari penelitian ini adalah untuk mengetahui efektivitas model pembelajaran kooperatif tipe Team Games Tournament (TGT) dan Numbered Head Together (NHT) terhadap hasil belajar matematika ditinjau dari motivasi belajar siswa. Penelitian ini merupakan true experiment dengan subjek seluruh siswa kelas VII di MTsN 7 Sleman. Teknik pengumpulan data yang digunakan yaitu teknik angket, tes dan dokumentasi. Instrumen tes hasil belajar matematika yang digunakan, memenuhi validitas, tingkat kesukaran, daya beda dan reliabilitas, sedangkan angket motivasi belajar memenuhi validitas dan reliabilitas. Analisis variansi (anava) dua arah digunakan untuk menganalisis data dan dilanjutkan dengan uji pasca anava. Hasil dari penelitian ini adalah: (1) terdapat perbedaan hasil belajar matematika antara siswa dengan perlakuan TGT dan NHT; (2) terdapat perbedaan hasil belajar siswa bermotivasi tinggi, sedang, dan rendah dan (3) tidak terdapat interaksi antara model pembelajaran dan motivasi belajar siswa terhadap hasil belajar matematika siswa. Penelitian ini diharapkan dapat menjadi acuan bagi penelitian berikutnya terkait pembelajaran TGT dan NHT.
\end{abstract}

Kata Kunci: Team Games Tournament, Numbered Head Together, motivasi belajar, hasil belajar matematika

\begin{abstract}
This research aims to determine the effectiveness of the Team Games Tournament (TGT) and Numbered Head Together (NHT) on mathematics achievement viewed from learning motivation. This research is true experiment research. The subjects were seventh-grade junior high school students at MTsN 7 Sleman. Data collection techniques used questionnaire, test, and documentation. The instrument of mathematics achievement test has been authenticated with the validity, difficulty level, efficacy number, and reliability, while the learning motivation questionnaire has been authenticated with validity and reliability. Two-way variance analysis technique (ANOVA) was used to analyze the data and continued with the post ANOVA test. This research resulted: (1) there are differences in mathematics achievement between students with TGT and NHT; (2) there are differences in mathematics achievement between student has high, medium, and low motivation
\end{abstract}


and (3) there is no interaction between learning models with students' learning motivation towards student mathematics achievements. This study is expected to be used as reference in future research related to learning TGT and NHT.

Keywords: Team Games Tournament, Numbered Head Together, learning motivation, mathematics achievement

\section{Pendahuluan}

Pendidikan diartikan sebagai usaha sadar dan terencana untuk mewujudkan pembelajaran yang menginspirasi dan menyenangkan sehingga peserta didik aktif, tertantang dan termotivasi untuk mengembangkan potensi dirinya selaras dengan bakat, minat, dan perkembangan fisik serta psiko-logisnya (Indonesia, 2017; Undang-Undang, 2015). Dalam upaya untuk merealisasikan pendidikan tersebut, diperlukan pembelajaran yang mampu memotivasi peserta didik untuk aktif di setiap kegiatan pembelajaran. Keaktifan tersebut tentunya akan berpengaruh positif terhadap hasil belajar matematika peserta didik (Achdiyat \& Lestari, 2016; Ramlah et al., 2015; Widyastuti \& Widodo, 2018). Oleh karena itu, pendidik perlu memilih strategi pembelajaran yang tepat agar peserta didik aktif dalam pembelajaran salah satunya dengan mengaplikasikan model pembelajaran kooperatif. Pelibatan siswa dalam pembelajaran kooperatif menghasilkan prestasi yang lebih tinggi, retensi yang lebih besar, perasaan yang lebih positif antar siswa dan materi pelajaran, dan akademik yang lebih kuat, dibandingkan dengan pembelajaran kompetitif dan individualistis (Johnson \& Johnson, 2011).

TGT merupakan pembelajaran kooperatif yang memberi kesempatan untuk saling berinteraksi dalam kelompok yang terdiri dari empat anggota dengan berbagai karakteristik akademik, gender maupun suku (Pello, 2018; Seran et al., 2018). Guru menjelaskan materi yang diberikan sementara peserta didik bersama kelompoknya mempelajari materi yang diberikan dan memastikan seluruh anggota memahami materi tersebut. Terakhir, kelompok-kelompok tersebut saling bertanding dalam turnamen mingguan (Slavin, 2010). NHT adalah pembelajaran kooperatif yang dirancang dalam bentuk diskusi kelompok dengan setiap anggotanya diberi nomor yang berbeda untuk mempelajari materi tertentu, selanjutnya guru memilih nomor secara acak dan peserta didik yang sesuai dengan nomor tersebut akan menjelaskan materi yang dipelajarinya (Al-Tabany, 2014; Duha, 2012). Berdasarkan penjelasan tersebut, TGT dan NHT mampu mengondisikan peserta didik untuk aktif dalam mempelajari materi dan berinteraksi satu sama lain dalam kelompok-kelompok diskusi sehingga penerapan kedua model pembelajaran tersebut dapat dikatakan sebagai salah satu cara yang dapat dipilih guru Copyright $@ 2021$

Buana Matematika :

Jurnal Ilmiah Matematika dan Pendidikan Matematika 
dalam menciptakan pembelajaran yang sesuai dengan harapan pemerintah. Pembelajaran yang sesuai harapan pemerintah tersebut tentunya akan berdampak positif terhadap prestasi belajar peserta didik.

Prestasi belajar matematika diartikan sebagai keberhasilan seseorang melakukan kegiatan belajar matematika sesuai dengan bobot yang dicapainya pada masa tertentu yang dinyatakan dengan angka atau perubahan tingkah laku (Bailey et al., 2012). Prestasi belajar tersebut menjadi salah satu tolak ukur untuk mengetahui kemampuan peserta didik pada aspek pengetahuan, sikap dan keterampilan. Di sisi lain, motivasi belajar adalah salah satu faktor yang berdampak positif terhadap prestasi belajar matematika peserta didik (Kurniawan \& Wustqa, 2014; Oktavianingtyas, 2013; Sulasteri, 2013).

Motivasi belajar diartikan sebagai kemauan, kebutuhan, keinginan, alasan maupun paksaan dari diri siswa untuk berpartisipasi dan berperilaku dalam situasi tertentu sehingga mencapai sukses dalam proses pembelajaran (Berger \& Karabenick, 2011; Turner et al., 2011). Motivasi belajar menumbuhkan rasa kebutuhan dan keinginan peserta didik untuk berpartisipasi dan berperilaku dalam mencapai kesuksesan belajar. Oleh karena itu, dalam pembelajaran kooperatif, motivasi belajar sangat penting karena dapat mempermudah peserta didik untuk memahami sebuah materi maupun mengondisikan diri untuk belajar secara mandiri bersama kelompoknya. Hal ini menunjukkan bahwa penerapam pembelajaran kooperatif pada peserta didik dengan motivasi belajar tinggi akan memaksimalkan prestasi belajar matematika.

Berdasarkan observasi yang telah dilakukan, diperoleh bahwa pembelajaran matematika di MTsN 7 Sleman masih terpusat pada guru. Hal ini tentunya membuat peserta didik tidak aktif sehingga tidak berkesempatan untuk menyusun struktur kognitifnya baik secara mandiri maupun kelompok. Selain itu, pembelajaran tersebut juga mengakibatkan peserta didik pasif dan tidak lebih dari mendengarkan materi yang diberikan guru sehingga memunculkan rasa bosan, kurang berusaha untuk menyelesaikan tugas-tugas dan dampak negatif lainnya. Akibat dari beberapa dampak negatif tersebut adalah rendahnya motivasi belajar yang pada akhirnya mengakibatkan tidak maksimalnya prestasi belajar matematika peserta didik. Hal ini didukung oleh hasil Ujian Tengah Semester (UTS) semester genap tahun ajaran 2018/2019 yang menunjukkan bahwa banyak peserta didik mendapat nilai di bawah Kriteria Ketuntasan Minimal (KKM) dengan KKM 75. Oleh karena itu, diperlukan solusi yang tepat untuk memperbaiki pembelajaran matematika di MTsN 7 Sleman.

Copyright (C) 2021

Buana Matematika :

Jurnal Ilmiah Matematika dan Pendidikan Matematika 
Pembelajaran kooperatif tipe NHT dan TGT merupakan model pembelajaran yang tepat untuk mengatasi permasalahan pembelajaran matematika di MTsN 7 Sleman karena dapat membuat peserta didik aktif dalam memahami materi pelajaran sekaligus berinteraksi antar peserta didik dalam kelompoknya. Selain itu, motivasi belajar merupakan komponen penting untuk mening-katkan prestasi belajar peserta didik. Berdasarkan hal tersebut, dilakukan penelitian yang dapat menunjukkan efektivitas penerapan dua model pembelajaran yaitu TGT dan NHT terhadap prestasi belajar matematika jika ditinjau dari motivasi belajar peserta didik kelas VII di MTsN 7 Sleman. Hasil dari penelitian ini diharapkan dapat memberikan gambaran penyelesaian permasalahan pembelajaran matematika dengan menerapkan TGT dan NHT sehingga dapat dijadikan referensi bagi penelitian selanjutnya.

\section{Metode}

Populasi pada penelitian eksperimen murni ini adalah seluruh peserta didik kelas VII di MTsN 7 Sleman. Sampel dipilih menggunakan cluster random sampling yaitu sampling yang membagi seluruh populasi menjadi kelompokkelompok sampel yang dipilih acak dengan pertimbangan bahwa masingmasing kelas diberikan pengajaran, kurikulum dan fasilitas yang sama (Acharya et al., 2013). Data dikumpulkan melalui teknik angket, tes dan dokumentasi. Tes prestasi belajar matematika pada materi bangun datar memenuhi validitas, tingkat kesukaran, daya beda dan reliabilitas, sedangkan angket motivasi belajar memenuhi validitas dan reliabilitas.

Anava dua arah digunakan untuk menganalisis data tes dan dilanjutkan dengan uji pasca anava yaitu uji komparasi ganda. Uji normalitas dan uji homogenitas perlu dilakukan sebelum anava dua arah sebagai uji prasyarat (Hocking, 2013). Pengkategorian skor angket motivasi belajar menjadi tiga kategori yaitu tinggi, sedang, dan rendah dapat dilihat pada Tabel 1 (Asrul et al., 2018; Pradilasari et al., 2019).

Tabel 1. Kategori Motivasi Belajar

\begin{tabular}{ccc}
\hline No. & Interval & Kategori \\
\hline 1. & $x>\bar{x}+S D$ & Motivasi Tinggi \\
2. & $\bar{x}-S D \leq x \leq \bar{x}+S D$ & Motivasi Sedang \\
3. & $x<\bar{x}-S D$ & Motivasi Rendah \\
\hline
\end{tabular}

Keterangan:

$x \quad$ : skor angket motivasi belajar

$\bar{x} \quad$ : skor rata-rata

$S D \quad$ : standar deviasi.

Copyright (C) 2021

Buana Matematika :

Jurnal Ilmiah Matematika dan Pendidikan Matematika 


\section{Hasil dan Pembahasan}

Data dalam pengujian hipotesis meliputi data prestasi belajar matematika yang digunakan ketika anava dua arah dan data motivasi belajar yang digunakan untuk mengelompokkan peserta didik dalam tiga kategori yaitu Motivasi Belajar Tinggi (MT), Motivasi Belajar Sedang (MS), dan Motivasi Belajar Rendah (MR). Hasil analisis data tes menggunakan anava dua arah dapat dilihat pada Tabel 2.

Tabel 2. Rangkuman Anava Dua Arah

\begin{tabular}{cccc}
\hline No. & Sumber & Fhitung & Ftabel \\
\hline 1. & Model Pembelajaran (A) & 51,745 & 4,01 \\
2. & Motivasi Belajar (B) & 3,778 & 3,16 \\
3. & Interaksi (AB) & $-4,181$ & 3,16 \\
\hline
\end{tabular}

Berdasarkan Tabel 2 pada model pembelajaran diperoleh Fhitung > Ftabel, artinya prestasi belajar matematika peserta didik yang diberi perlakuan TGT dan NHT mengalami perbedaan. Pada variabel motivasi belajar diperoleh juga bahwa Fhitung > Ftabel, artinya prestasi belajar matematika peserta didik dengan MT, MS, dan MR mengalami perbedaan. Pada kolom interaksi diperoleh Fhitung < Ftabel, artinya model pembelajaran dan motivasi belajar tidak mengalami interakti terhadap prestasi belajar matematika. Hasil pada uji hipotesis untuk interaksi ini mengakibatkan tidak diperlukannya uji pasca anava (Hocking, 2013). Sementara itu, dengan melihat rataan marginal antar baris dan antar kolom, model pembelajaran dan motivasi belajar yang lebih baik dapat diketahui (Hocking, 2013). Hasil membandingkan rataan marginal antar baris dan antar kolom tersebut menjadi kesimpulan ketika membandingkan rataan antar sel. Secara keseluruhan, dapat dikatakan bahwa prestasi belajar matematika peserta didik yang diberi perlakuan TGT lebih baik daripada NHT pada peserta didik dengan MT, MS dan MR.

Penjelasan menggambarkan bahwa TGT lebih efektif daripada NHT. Tentunya hal ini didukung oleh keunggulan dari TGT itu sendiri. Komponen dari TGT adalah: (1) presentasi di kelas; (2) tim; (3) game; (4) tournament, dan (5) rekognisi tim (Slavin, 2010). Kelima komponen tersebut akan dibahas secara lebih detail pada penjelasan selanjutnya.

\section{Presentasi di Kelas}

Pada kegiatan ini, pokok-pokok materi yang akan dipelajari diberikan oleh guru dalam bentuk presentasi. Presentasi dapat berupa pengajaran secara langsung, diskusi maupun pengajaran yang melibatkan audiovisual (Slavin, 2010). Berdasarkan pengertian tersebut, dapat dikatakan bahwa guru Copyright $@ 2021$

\section{Buana Matematika :}

Jurnal Ilmiah Matematika dan Pendidikan Matematika 
berperan sebagai pihak yang mengenalkan materi kepada peserta didik dalam bentuk presentasi. Pada dasarnya, presentasi masih tergolong biasa dan sering dilakukan oleh guru. Namun yang membedakan presentasi pada TGT dengan pembelajaran lain adalah guru terfokus untuk menyampaikan pokok-pokok materi sementara peserta didik terfokus untuk mempelajari lebih dalam materi pokok yang telah dipresentasikan guru. Artinya, peserta didik secara aktif dan mandiri mempelajari dan mencari setiap hal yang terkait dengan materi pokok yang disampaikan guru. Hal-hal yang telah ditemukan oleh peserta didik tentunya dapat bersifat positif maupun negatif. Tugas bagi peserta didik itu sendiri untuk memilih dan menyimpulkan materi manakah yang bersifat positif dan erat kaitannya dengan materi pokok yang dipresentasikan oleh guru. Tahap ini memberikan pengalaman belajar bermakna karena secara tidak langsung peserta didik menemukan materi dan mengaitkannya dengan materi yang telah dimiliki sebelumnya (Agra et al., 2019; Dahar, 2011). Belajar bermakna tentunya akan menghasilkan pembelajaran yang berkualitas sehingga prestasi belajar matematika dapat optimal (Yogihati, 2010).

\section{Tim}

Empat atau lima peserta didik dalam satu tim bertugas saling memastikan semua anggota aktif belajar dan mempersiapkan diri menghadapi kuis. Kegiatan ini membuat peserta didik belajar secara mandiri bersama kelompoknya sehingga terjadi tukar pikiran antar peserta didik. Kemandirian belajar tersebut terbentuk melalui kegiatan saling memastikan dan mempersiapkan diri dalam menghadapi kuis (Fahradina \& Ansari, 2014). Pada akhirnya kemandirian belajar yang telah terjadi dapat berpengaruh positif terhadap prestasi belajar matematika dari peserta didik (Sulistyowati et al., 2019).

\section{Games, Tournament dan Rekognisi Tim}

Games atau permainan pada TGT memuat pertanyaan-pertanyaan pada kartu bernomor untuk menguji pengetahuan yang didapatkan dalam kegiatan presentasi kelas maupun kegiatan dalam kelompok. Permainan dilaksanakan di sebuah meja yang diikuti oleh peserta didik sebagai perwa-kilan kelompoknya. Jika pertanyaan dapat dijawab dengan benar dan tepat, maka peserta didik berhak memperoleh skor. Skor tersebut akan dikumpulkan peserta didik untuk turnamen. Sementara itu, tournament atau turnamen adalah kumpulan dari permainan yang sebelumnya ditandingkan menjadi 4 
meja turnamen. Adapun formasi dari turnamen tersebut dapat dilihat pada Gambar 1.
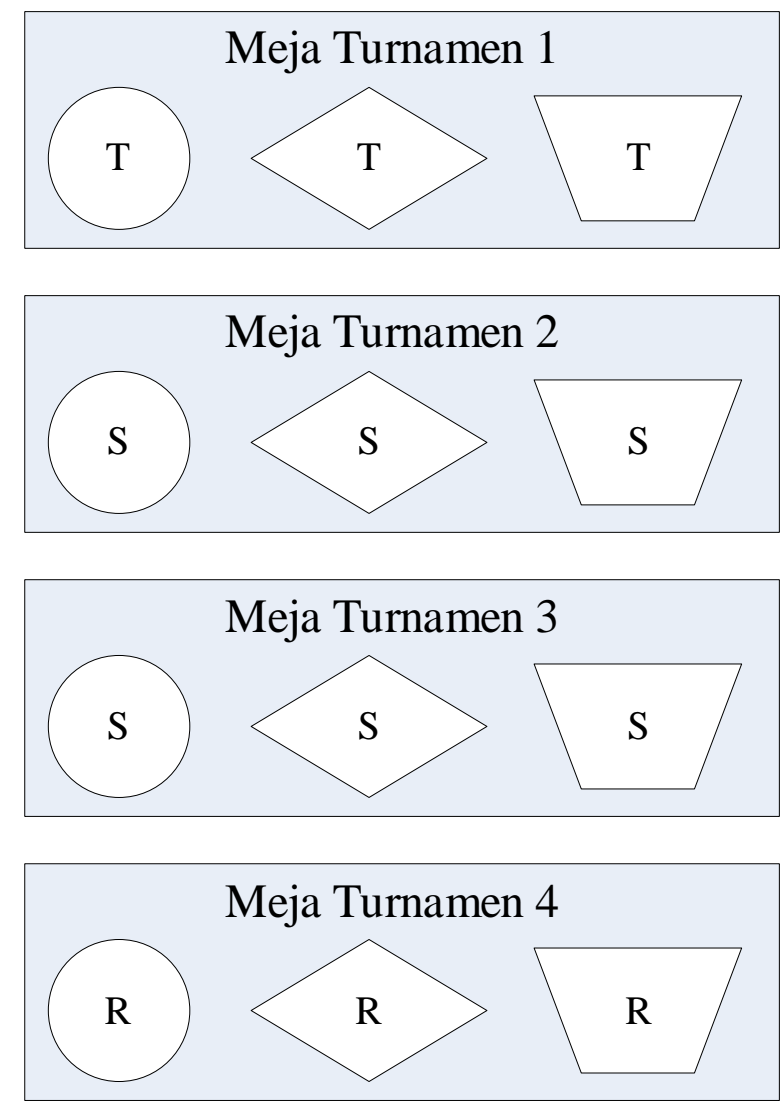

Gambar 1. Formasi Tournament TGT

Gambar 1 menunjukkan formasi turnamen yang dilaksanakan di akhir minggu. Pada gambar tersebut, terdapat 4 meja turnamen yang masingmasing berisi 3 peserta. Dalam satu meja turnaamen terdiri dari 1 anggota kelompok lingkaran, 1 anggota kelompok belah ketupat dan 1 anggota kelompok trapesium. T menunjukkan peserta didik yang memperoleh skor tertinggi di kelompoknya dalam permainan sebelumnya, $\mathrm{S}$ sedang dan $\mathrm{R}$ rendah. Pada setiap meja turnamen, diadakan permainan seperti sebelumnya. Peserta didik yang memperoleh skor tertinggi menjadi pemenang dalam turnamen tersebut dan akhirnya memperoleh penghargaan tim sebagai bentuk rekognisi tim.

Kegiatan yang terjadi pada permainan maupun turnamen membuat peserta didik berpikir kritis dan kompetitif dalam keadaan tertentu. Jiwa kompetitif peserta didik adalah salah satu indikator bagi seorang guru bahwa peserta didik tersebut patut diberikan pendidikan dan pengajaran yang sesuai

Copyright $@ 2021$

Buana Matematika :

Jurnal Ilmiah Matematika dan Pendidikan Matematika 
dengan kebutuhannya sehingga dapat mening-katkan prestasi belajar matematika peserta didik tersebut.

Penjelasan 5 komponen TGT tersebut memberikan gambaran keunggulan TGT hingga dikatakan lebih efektif daripada pembelajaran lain. Namun demikian, TGT tetap memiliki beberapa kekurangan yang harus diperhatikan oleh guru. Dalam pelaksanaannya, TGT perlu pengelolaan kelas yang baik agar permainan atau turnamen dapat terlaksana sesuai dengan rencana pembelajaran. Permasalahannya, permainan dapat memunculkan keaktifan peserta didik yang berlebihan sehingga menimbulkan kegaduhan di kelas. Apabila guru tidak mempersiapkan solusi untuk permasalahan ini, tentunya pembelajaran tidak sesuai harapan. Oleh karena itu, dalam setiap kelompok harus berisi peserta didik dengan karakteristik yang berbeda. Artinya, peserta didik dengan karakter kepemimpin-an yang baik tentunya mampu mengkondisikan anggotanya agar lebih kondusif dalam pembelajaran sehingga mampu meminimalisir permasalahan yang muncul dalam TGT.

Pada penjelasan sebelumnya disimpulkan pula prestasi belajar matematika peserta didik dengan MT lebih baik daripada MS dan MR, MS lebih baik daripada MR. Selain itu, model pembelajaran dan motivasi belajar tidak mengalami interaksi terhadap prestasi belajar matematika. Hasil tersebut menunjukkan tidak ada hubungan antara model pembelajaran dengan motivasi belajar. Artinya, prestasi belajar matematika peserta didik yang diberi perlakuan TGT tetap lebih baik daripada NHT, baik pada peserta didik dengan MT, MS dan MR. Hal ini berarti tinggi atau rendahnya motivasi belajar tidak berpengaruh terhadap hasil penerapan TGT dan NHT. Rasionalitas hasil tersebut dapat dilihat dalam komponen-komponen TGT yang telah dijelaskan sebelumnya yaitu peserta didik akan secara aktif dan mandiri ketika TGT diterapkan. Oleh karena itu, peserta didik dengan MR tetap mengalami belajar yang menarik dan menyenangkan, sehingga prestasi belajar peserta didikpun akan mengikuti hasil dari penerapan model pembelajaran.

Hasil dan pembahasan sebelumnya menunjukkan TGT adalah model pembelajaran kooperatif yang efektif diterapkan untuk mengatasi permasalahan dalam pembelajaran Bangun Datar, sehingga pembelajaran akan lebih berkualitas dan mampu meningkatkan prestasi belajar matematika peserta didik.

\section{Simpulan}

Copyright (C) 2021

Buana Matematika :

Jurnal Ilmiah Matematika dan Pendidikan Matematika 
Simpulan pada penelitian ini adalah: (1) hasil belajar matematika peserta didik yang diberi perlakuan TGT lebih baik daripada NHT; (2) hasil belajar matematika peserta didik dengan MT lebih baik daripada MS dan MR, serta MS lebih baik daripada MR; (3) model pembelajaran dan motivasi belajar tidak mengalami interaksi terhadap hasil belajar matematika peserta didik. Hal ini berarti bahwa TGT akan tetap lebih efektif daripada NHT meskipun diterapkan pada peserta didik dengan MT, MS maupun MR.

Penelitian ini terfokus pada efektivitas penerapan NHT dan TGT terhadap prestasi belajar matematika dalam pembelajaran Bangun Datar. Oleh karena itu, pada penelitian selanjutnya dapat diperluas dalam hal variabel terikat, pokok bahasan atau menggunakan variabel bebas lain terkait NHT dan TGT dengan tinjauan pustaka yang tepat, sehingga penelitian menjadi lebih bervariasi.

\section{Daftar Pustaka}

Acharya, A. S., Prakash, A., Saxena, P., \& Nigam, A. (2013). Sampling: Why and how of it. Indian Journal of Medical Specialties, 4(2), 330-333.

Achdiyat, M., \& Lestari, K. D. (2016). Prestasi Belajar Matematika Ditinjau dari Kepercayaan Diri dan Keaktifan Siswa di Kelas. Formatif: Jurnal Ilmiah Pendidikan MIPA, 6(1).

Agra, G., Formiga, N. S., Oliveira, P. S. de, Costa, M. M. L., Fernandes, M. das G. M., \& Nóbrega, M. M. L. da. (2019). Analysis of the concept of Meaningful Learning in light of the Ausubel's Theory. Revista Brasileira de Enfermagem, 72(1), 248-255.

Al-Tabany, T. I. B. (2014). Mendesain model pembelajaran inovatif, progresif, dan kontekstual. Jakarta: Prenadamedia Group.

Asrul, A., Ridlo, S., \& Susilo, S. (2018). Creative Thinking Analysis, Motivation and Concept Mastery on Learning of Cooperative Discovery Model in Elementary School. Journal of Primary Education, 7(1), 48-56.

Bailey, D. H., Hoard, M. K., Nugent, L., \& Geary, D. C. (2012). Competence with fractions predicts gains in mathematics achievement. Journal of Experimental Child Psychology, 113(3), 447-455.

Berger, J.-L., \& Karabenick, S. A. (2011). Motivation and students' use of learning strategies: Evidence of unidirectional effects in mathematics classrooms. Learning and Instruction, 21(3), 416-428.

Dahar, R. W. (2011). Teori-teori belajar dan pembelajaran. Jakarta: Erlangga,

Copyright (C) 2021

Buana Matematika :

Jurnal Ilmiah Matematika dan Pendidikan Matematika 
$136,141$.

Duha, M. (2012). Cooperative Learning: metode, teknik, struktur dan model penerapan. Yogyakarta: Pustaka Pelajar.

Fahradina, N., \& Ansari, B. I. (2014). Peningkatan Kemampuan Komunikasi Matematis dan Kemandirian Belajar Siswa SMP dengan Menggunakan Model Investigasi Kelompok. Jurnal Didaktik Matematika, 1(2).

Hocking, R. R. (2013). Methods and applications of linear models: regression and the analysis of variance. John Wiley \& Sons.

Indonesia, P. R. (2017). Permendikbud No. 22 Tahun 2016 tentang Standar Proses Pendidikan Dasar dan Menengah. Jakarta: Kementrian Pendidikan dan Kebudayaan.

Johnson, D. W., \& Johnson, R. T. (2011). Cooperative learning. The Encyclopedia of Peace Psychology.

Kurniawan, D., \& Wustqa, D. U. (2014). Pengaruh perhatian orangtua, motivasi belajar, dan lingkungan sosial terhadap prestasi belajar matematika siswa SMP. Jurnal Riset Pendidikan Matematika, 1(2), 176-187.

Oktavianingtyas, E. (2013). Studi tentang faktor-faktor yang mempengaruhi prestasi belajar mahasiswa program studi pendidikan matematika FKIP Universitas Jember. KadikmA, 4(2).

Pello, A. C. S. (2018). KEEFEKTIFAN PEMBELAJARAN KOOPERATIF TIPE TEAMS GAMES TOURNAMENT (TGT) BERBANTUAN MEDIA KAHOOT UNTUK TOPIK PERSAMAAN KUADRAT PADA SISWA KELAS X SMA IPH 2 SURABAYA. Buana Matematika: Jurnal Ilmiah Matematika Dan Pendidikan Matematika, 8(2), 89-100.

Pradilasari, L., Gani, A., \& Khaldun, I. (2019). Pengembangan media pembelajaran berbasis audio visual pada materi koloid untuk meningkatkan motivasi dan hasil belajar siswa SMA. Jurnal Pendidikan Sains Indonesia (Indonesian Journal of Science Education), 7(1), 9-15.

Ramlah, R., Firmansyah, D., \& Zubair, H. (2015). Pengaruh Gaya Belajar dan Keaktifan Siswa Terhadap Prestasi Belajar Matematika (Survey Pada SMP Negeri di Kecamatan Klari Kabupaten Karawang). Majalah Ilmiah SOLUSI, 1(03).

Seran, E. B., Ladyawati, E., \& Susilohadi, S. (2018). PENGARUH MODEL PEMBELAJARAN KOOPERATIF TIPE TGT (TEAMS GAMES Copyright $(2021$

Buana Matematika :

Jurnal Ilmiah Matematika dan Pendidikan Matematika 
TOURNAMENT) TERHADAP HASIL BELAJAR MATEMATIKA SISWA. Buana Matematika: Jurnal Ilmiah Matematika Dan Pendidikan Matematika, 8(2), 115-120.

Slavin, R. E. (2010). Co-operative learning: what makes group-work work. The Nature of Learning: Using Research to Inspire Practice, 161-178.

Sulasteri, S. (2013). Faktor-Faktor Yang Mempengaruhi Prestasi Belajar Mahasiswa Jurusan Pendidikan Matematika Fakultas Tarbiyah dan Keguruan UIN Alauddin Makassar. MaPan: Jurnal Matematika Dan Pembelajaran, 1(1), 151-177.

Sulistyowati, F., Kuncoro, K. S., Setiana, D. S., \& Purwoko, R. Y. (2019). Solving high order thinking problem with a different way in trigonometry. Journal of Physics: Conference Series, 1315(1), 12001.

Turner, J. C., Warzon, K. B., \& Christensen, A. (2011). Motivating mathematics learning: Changes in teachers' practices and beliefs during a nine-month collaboration. American Educational Research Journal, 48(3), 718-762.

Undang-Undang, R. I. (2015). No. 20 Tahun 2003 tentang Sistem Pendidikan Nasional. Kementerian Agama.

Widyastuti, E., \& Widodo, S. A. (2018). Hubungan Antara Minat Belajar Matematika Keaktifan Siswa dan Fasilitas Belajar disekolah dengan Prestasi Belajar Matematika Siswa Kelas X SMK Se-Kecamatan Umbulharjo. Prosiding Seminar Nasional Pendidikan Matematika Etnomatnesia.

Yogihati, C. I. (2010). Peningkatan Kualitas Pembelajaran Fisika Umum Melalui Pembelajaran Bermakna dengan Menggunakan Peta Konsep. Jurnal Pendidikan Fisika Indonesia, 6(2). 
Jurnal Ilmiah Matematika dan Pendidikan Matematika

Vol. 11 No. 1 (2021)

Copyright () 2021

Buana Matematika :

Jurnal Ilmiah Matematika dan Pendidikan Matematika 